\title{
Guia de Fontes Literárias para o Estudo da História da Educação na Bahia
}

Pesquisadora: Maria Regina Filgueiras Antoniazzi Instituição: Universidade Federal da Bahia (UFBa) Fonte financiadora: Instituto Nacional de Estudos e Pesquisas Educacionais (INEP)

\section{Introdução}

A idéia de realizar um estudo sobre a história da educação através da literatura surgiu no contexto de uma discussão nacional, a IX Reunião Anual da Associação Nacional de PósGraduação em Educação (ANPEd), realizada no Rio de Janeiro, em 1988. Discutia-se, na época, a necessidade de ampliação das fontes de pesquisa sobre a história da educação no Brasil, incluindo-se, ao lado das fontes documentais usuais, fontes não-convencionais como registros fotográficos e literatura. Os trabalhos da professora Clarice Nunes deram uma contribuição valiosa para a elaboração desse projeto de pesquisa, assim como o artigo da professora Coriolinda Carvalho (1988)', que nas obras: O Coruja de Aluísio Azevedo, O Ateneu, de Raul Pompéia, e Doidinho, de José Lins do Rego, analisa as relações na escola e os processos pedagógicos da época. Pedagogia que se apoiava na palmatória como processo mais convincente para o aprendizado, e que encontrava no internato campo fértil para sua aplicação.

Esse guia de fontes visa, essencialmente, selecionar e catalogar autores e obras literárias, sob a forma de romance, novela ou conto, que direta ou indiretamente revelem e desvelem as relações sociais da educação, como processo de socialização humana. Propõe-se, também, a produzir resenhas das obras estudadas, utilizando a metodologia de enfoque histórico.

No momento, a equipe de trabalho percorre três caminhos paralelos, mas intercorrentes. Coriolinda Carvalho e Evandro Ubiratan de Souza explicam:

O primeiro é convencer-se e convencer de que a obra literária, co-

"A Literatura como fonte para estudo da

1 CARVALHO, Coriolinda Vasconcelos de história da educação: um exemplo". Seminário Livre de Pesquisa, Faculdade de Educação/Universidade Federal da Bahia, 1988. (mimeo). 
mo, alias, qualquer manifestação artística, é uma fonte fidedigna e segura para o estudo de fatos sociais, desde que devidamente abordada e compreendida; o segundo é a busca e registro da obra literária em si, como manifestação humana completa e autônoma, e como matéria-prima para o guia a ser elaborado; o terceiro se direciona para o confronto (discordante ou concordante) da visão de educação formal, como subtraída da obra literária, com aquela passada e repassada pela história tradicional e oficial.

Carvalho, no artigo, constata que qualquer obra literária se constitui numa modalidade especial de comunicação, pois ao mesmo tempo em que se refere a uma forma especial, autônoma e original de se comunicar, independente de quaisquer condicionamentos, exprime aspectos da realidade, o discurso da cultura. Afinal, ela se constitui em uma manifestação artística, o que faculta seu subjetivismo e a possibilidade do significado estético.

É a partir desse entendimento, aparentemente paradoxal, que se considera relevante levantar fontes literárias que possam se constituir em material de estudo para a história da educação. O importante é estabelecer uma distinção de disciplinas, lembrando que o relevante nesta questão não é o va- lor literário da obra, mas $\operatorname{sim} \mathrm{o}$ elemento histórico-social que ela documenta. $\mathrm{O}$ valor estético é matéria da crítica literária.

O que se propõe com o projeto é um estudo que inventarie e classifique obras que possam auxiliar a pesquisa histórica na compreensão de uma época e de um contexto determinados. Assim sendo, o interesse estará voltado para os elementos sociais e históricos e as circunstâncias do meio que influíram na sua composição, pois estes são os aspectos capitais para os estudos dos historiadores.

\section{O processo de pesquisa}

O projeto está dividido em cinco etapas: levantamento de autores e obras, estudo pré-analítico das obras selecionadas, produção e categorização de resenhas dessas obras e elaboração do guia de fontes.

Utilizou-se, inicialmente, o livro Intelectuais e escritores baianos: breves biografias, de Marieta Alves, para se identificar os autores e as obras literárias que pudessem oferecer informações sobre a história da educação baiana. O passo seguinte foi fichar os autores selecionados, especificando, quando identificadas, as obras que deveriam ser analisadas. Amplia-se e complementa-se esse trabalho com três dicionários de Literatura: 
o de Jacinto do Prado Coelho, o de Celso Luft, e o de José Paulo Paes Massaud Moisés.

$\mathrm{O}$ produto desse trabalho resultou no fichamento de 43 autores.

Paralelamente ao levantamento e fichamento de autores, estudaram-se os autores: Pedro Calmon, História da literatura baiana; Antonio Cândido, Literatura e sociedade; Otaíza O. Romannelli, História da educação no Brasil -1930-1973. Outras obras, como a de Primitivo Moacir, $A$ instrução e o Império - 1854-1888 e Ementário da legislação educacional baiana no Período Republicano 1889-1983, organizada pelo professor Luiz Henrique Tavares, estão selecionadas para análise.

Iniciou-se a leitura de algumas obras literárias, e realizaram-se resenhas. Essa atividade vem sendo desenvolvida no sentido de se verificar, na obra, aspectos relacionados com a visão que a personagem tem da escola, do professor e do diretor; as relações professor/aluno, aluno/aluno, família/escola; o status social do professor; a organização da escola e da sala de aula; o currículo: disciplinas, conteúdos, metodologia, avaliação etc.

Já estão resenhados os seguintes contos de Graciliano Ramos do livro Infância: "Leitura", que retrata o primeiro contato de um garoto com as letras, atrás de um balcão de loja de seu pai; "Escola", que retrata a escola como algo ruim, lugar onde se educam crianças rebeldes, onde o diretor é um ditador e a criança tem medo de ir à escola; " $\mathrm{D}^{\mathrm{a}}$ Maria", professora que cativa os alunos com sua bondade; "Um novo professor", história de um professor negro, que expressa seu preconceito racial na sala de aula, deixando os alunos temerosos; "Uma criança infeliz", que retrata a marginalização de uma criança na escola. É, também do mesmo autor, do livro Viventes dos alagados, o conto "Professores improvisados".

De Mauro Vasconcelos, Meu pé de laranja lima, foi resenhado o capítulo "O passarinho, a escola e a flor", que retrata as relações família/escola, professor/aluno e o conteúdo curricular da escola.

De Viriato Corrêa, Cazuza, foram resenhados os capítulos "As calcinhas", que retrata a festa da palmatória, e "O primeiro dia", que descreve a decepção de Cazuza com a escola.

Estão previstos outros procedimentos, como por exemplo: agrupar as resenhas por categorias (professor, aluno/escola, professor/ preconceito, relação aluno/professor, relação criança/conhecimento etc.); viajar para o interior da Bahia, regiões de Conquista e Ilhéus/ Itabuna, para levantar obras (crônicas, narrações etc.) de autores 
locais; categorização do autor pe-pelo nível de abrangência da obra. Têm-se constituído importante para o desenvolvimento da pesquisa as seguintes questões: a) ampliar o universo das obras literárias do período que definimos - século XIX e primeira metade do século $\mathrm{XX}$; b) manter o exercício de elaboração das resenhas para se compreender melhor a questão das relações entre categorias de análise e espaço-tempo histórico; c) manter o estudo de autores que nos possam ajudar a compreender melhor o período que elegemos, e de autores que de alguma forma subsidiem a análise das obras literárias, do ponto de vista histórico. Estão previstas, para os próximos seis meses, as seguintes atividades:

- prosseguir com o levantamento de obras e autores e fichá-los;

- analisar previamente as o-bras indicadas, registrando em fichas os indicadores dos aspectos educacionais da obra;

- elaborar resenhas das o-bras: Cazuza, de Viriato Corrêa; $A$ normalista, de Adolfo Caminha; $A$ professora Hilda, de Lúcio Cardoso; $O$ Coruja, de Aluísio Azevedo; Doidinho, de José Lins do Rego e O Ateneu, de Raul Pompéia;

- categorizar as resenhas, considerando a identidade temática dos conteúdos educacionais.
Finalizando, reafirma-se que é possível utilizar a literatura como fonte não-convencional para o estudo da história da Educação; fonte alternativa sim, mas viva e lúcida, de fatos e fenômenos da história.

Em síntese, este projeto se propõe a um exercício para determinação das relações de essência que descrevem o espaço-tempo histórico da educação brasileira no século XIX e nas primeiras cinco décadas do século XX.

\section{Referências bibliográficas}

CARVALHO, Coriolinda Vasconcelos de. A literatura como fonte para estudo da história da educação: um exemplo. [S.1.: s.n.], 1988. mimeo. Apresentado no Seminário livre de Pesquisa, UFBA, Faculdade de Educação, 1988.

NUNES, Clarice. Guia prelimi nar de fontes para a história da educação brasileira: reconstituição de uma experiência. Revista Brasileira de Estudos Pedagógicos, Brasília, v.71, n.167-168-169, jan./dez. 1990.

SEMINÁRIO livre de pesquisa. Salvador: UFBA, Faculdade de Educação, 1988. 
SERPA, Luiz Felippe Perret. Ciência e historicidade. Salvador: Ed. do Autor: Multpress,
1991. SEMINÁRIO Livre de Pesquisa. Salvador: UFBA, Faculdade de educação, 1988. 